\title{
Light Pollution and Smart Outdoor Lighting
}

\author{
Zehra Karagoz Kucuk and Nazmi Ekren
}

\begin{abstract}
With the developing technology and increasing urbanization, many problems have started to arise in the use of energy resources and nature. In addition to environmental effects, energy-saving considerations constitute the main purpose of any proposed smart system. In outdoor lighting, along with the use of energy-efficient bulbs, the lighting should be done with the right method and the right way. In addition to these, an intelligent system integrated with an automatic control mechanism is needed. Incorrect outdoor lighting causes unnecessary energy consumption as well as light pollution and CO2 emission. These situations have negative consequences on both mental and physical health of the human, as well as on other living creatures and nature. Therefore, smart outdoor lighting systems offer an essential solution in preventing negative consequences that may occur with incorrect outdoor lighting.

In this study, outdoor lighting requirements, light pollution and smart cities are examined in detail and the smart outdoor lighting systems within the scope of the smart cities are emphasized. As a result, the importance and necessity of the smart outdoor lighting system which provides energy-efficient and environmentally friendly structures by enabling street lamps to work smartly and efficiently are outlined.
\end{abstract}

Index Terms - Smart cities, lighting pollution, outdoor lighting, smart outdoor lighting, energy saving, dark sky

\section{INTRODUCTION}

C ITIES ARE unquestionably not only the cause but also the answer to society's sustainability problems. Urbanization is the interaction between the physical growth and socio-economic development of a city that consumes a significant amount of energy and resources. The driving forces underlying urban expansion can be listed as: population, economy, demands and needs, etc. Knowing these forces facilitates academic research as well as guides in policy drafting and practical city management. Researchers need some data to map urbanization and examine driving socioeconomic variables in cities. To address this need, they have to make use of innovative remotely sensed datasets such as nighttime lights data (NTL) [1]. To understand urbanization,

ZEHRA KARAGOZ KUCUK, is with Department of Electrical, Vocational School, University of Dogus, Istanbul, Turkey, (e-mail: zkaragoz@dogus.edu.tr). (iD https://orcid.org/0000-0002-7578-153X

NAZMI EKREN, is with Department of Electrical and Electronics Engineering, University of Marmara, Istanbul, Turkey,(e-mail: nazmiekren@marmara.edu.tr). (D) https://orcid.org/0000-0003-3530-9262

Manuscript received February 4, 2021; accepted April 27, 2021. DOI: $\underline{10.17694 / \text { bajece. } 874343}$ that is, the ongoing movement of people into urban environments; It is critical to obtain essential, reliable and consistent data. After the 1970s, data such as remote sensing satellite images, data received via sensors, etc. have become alternative data sources for monitoring urbanization in a more repeatable and broad manner. These data sources are more affluent sources of information than traditional measurement data [2]. In this context, reliable data sources are needed to determine the extent of urbanization and to meet demands and provide appropriate solutions.

Lighting has become an essential factor in making cities suitable for livable spaces to live in all comfort conditions [3]. Proper lighting is crucial in economic, environmental and social aspects. In European Union countries, lighting requirements for frequently used outdoor work areas are regulated according to the standards. However, since the lighting of natural and architectural objects is not standardized, recommendations have been made in technical reports such as the Commission Internationale de l'Eclairage (CIE) report [4]. Excessive or improper lighting causes adverse effects on the environment and the living conditions. This situation has brought light pollution, which is defined as an unwanted skylight, into question due to population growth and increasing outdoor lighting per person. Astronomers and researchers in this century have had to struggle with light pollution [5].

The smart city concept has brought up many technological and scientific problems, including light pollution. Light pollution, which occurs as a direct result of incorrect external lighting, has various negative effects on the economy, ecology and health [6]. Light pollution has a large number of negative effects on individuals, ecosystems, astronomy and energy consumption, just as it is caused by sound, garbage and chemical products. All this occurs as a result of human activities. Some examples of these negative effects are; hormonal disruption, sleep disturbance, cancer, unsafe driving, etc. Also, light pollution has negative effects on some plants and animals $[7,8,9]$. Dealing with such problems is also included within the scope of smart cities.

In 2017, a report called 'CITYkeys' was prepared within the scope of EU projects, which includes determining factors for smart cities. With this report, smart city and smart city projects were defined and Key Performance Indicators were selected for the goals of transforming into smart cities. The main themes of the indicators are as follows; propagation, planet, governance, prosperity and people. And these are determined in line with the needs of smart cities. CITYkeys ultimate goal is to support the acceleration of large-scale deployment of smart city solutions and services to impact the significant societal challenges of urbanization [10]. Key 
BALKAN JOURNAL OF ELECTRICAL \& COMPUTER ENGINEERING, Vol. 9, No. 2, April 2021

indicators in this report and the report itself are important guides in the process of transformation into smart cities.

New generations will have significant losses that we have yet to anticipate in a world that is rapidly losing its darkness. Some of these losses have been scientifically revealed and the threat can now be seen more clearly [11]. It is seen that the most logical solution in the effective struggle against light pollution, in meeting the data requirements needed with the increase of urbanization and in data management, is to design smart cities. As a result; It has become crucial and necessary to design smart systems and transform them into smart cities by benefiting from the blessings of developing science and technology to meet the demand of the increasing urban population, to contribute to the environment and economy, to facilitate research and studies in many specific areas (such as providing the dark skies needed by astronomers).

\section{A. Smart Cities}

The word "smart" refers to an automated mechanism adopted to perform the desired activity in space [12]. For example, in the smart kitchen of a smart home, the materials in the kitchen can be controlled remotely/closely accessed, intervention in unusual situations occurring in the kitchen, and comfort can be increased in line with human needs with smart systems, and energy, time savings can be achieved [13]. Similarly, smart cities should meet daily, environmental, security, economic, commercial, social, health needs. It must be able to respond to their needs intelligently. Cities play an important role socially and economically around the world and have a significant impact on the environment. The concept of a smart city has become very popular in international politics and scientific literature in the last 25 years [14]. The concept of "smart city" that emerged in the late 90 s includes the integration of all information and communication technologies to manage the urban system effectively [15]. "Smart city" is defined by IBM as "using information and communication technology to perceive, analyze and integrate basic information of basic systems in working cities" $[16,17]$. The smart city can also be defined as a city ecosystem that uses connected technologies to improve daily city activities and to make near-real-time smart decisions [18].

The concept of a smart city has many definitions and interpretations in the literature. The definitions made by some researchers in their studies are as follows: The smart city is defined by the capacity to combine people, technological innovations and data to develop a flexible, sustainable and robust infrastructure that provides first-class governance to its residents. Transforming an urban city into a smart city requires community-focused efforts among administration, industry, experts, citizens and researchers [19].; Smart city platforms are ecosystems where governments can provide their services using the transformative power of technologies, but at the same time enable citizens to participate in a democratica dialogue and co-creation of values [20]. The smart city is a paradigm for managing the challenge of urban life, increasing spending, reducing expenses and enhancing the value of the daily life of its residents. It has become extremely critical to discover innovative solutions present to make cities smarter and more efficient. In this context, countries all over the world adapt to smart cities [21].; The smart city emphasizes the local management's ability to cooperate with other organizations (IT companies, local communities, local business environment) to improve and adapt better policies that are to maximize the benefits of a strategic partnership [22].; It can be said that a smart city is an effective integration of smart planning ideas, smart management methods and smart development approach [17].; According to Zlámal, in recent years, there has been increased attention on the quality of life in connection with the concept of "smart city", which has become the subject of worldwide debate. The concept of "smart city" uses modern technology to streamline governance, innovate local sustainable development approaches, and more. It offers a wide range of individual freedom of application while paying attention to the environment [23].

According to the United Nations, $55 \%$ of people worldwide today live in cities, and this increase is estimated to be $68 \%$ by 2050 [24]. In this case, it is anticipated that many problems will arise in the management of these cities and in providing a reasonable quality of life for their citizens. A suitable solution for these challenges; to transform traditional cities into smart cities [25, 26]. Also, the international data company (IDC) estimates that spending on smart cities globally will rise to $\$$ 158 billion by 2022 (doubling from $\$ 80$ billion in 2018) [27]. Therefore, it is important to take into account economic possibilities when implementing smart city strategies [28]. The transition to smart systems is significant in economic, social and environmental aspects in today's world, which is globalizing and living in the "industry 4.0" era. Sustainable development has become increasingly dependent on the best management of urban growth as urbanization continues (mostly in low and middle-income countries where urbanization is expected to be the fastest) [29]. Due to such rapid urban population growth worldwide, the concept of smart cities needs to be understood more deeply to provide livable conditions [25]. Increasing urbanization impairs the ability of cities to create a livable environment for their citizens. In addition to the population growth of cities, daily commutes to and from workplaces are also increasing. This increases the pressure on the existing infrastructure and causes both discomfort and economic losses [30].

Many smart city attempts are currently underway around the world, and this tendency is expected to increase in the coming years. Such attempts should be tailored to the needs and circumstances of each government to expand or create public value for stakeholders [31]. When designing smart cities, whether technologies make the city smart; whether the city is energy efficient, automatic and environmentally friendly; It is important to ask questions about whether citizens can access justice, safety, jobs, education and culture [28]. The basic idea is to transform every asset of a traditional city into an autonomous object that automatically carries out its activity using modern technologies, without significant outside assistance. The basic assets of a smart city; smart infrastructure, smart management, smart policies, smart health services, smart transportation, smart agriculture, smart education, smart economy, smart environment, smart industry, smart energy, smart security, smart communication, smart 
BALKAN JOURNAL OF ELECTRICAL \& COMPUTER ENGINEERING, Vol. 9, No. 2, April 2021

outdoor lighting etc.[12]. The smart economy focuses mostly on competitiveness, the ability to adapt to changes, and flexibility. Smart mobility refers to sustainable, safe and innovative transport systems. Smart people focus on human capital and citizens' participation in public life. The smart environment preserves natural resources. Smart living often contributes to improving the quality of life in the city, from housing to culture. Smart governance is mostly linked to transparency [32].

The integration of the city and its citizens' systems is considered at the centre of the essence of smart cities. Smart cities often try to digitally connect and integrate services in a city to provide efficient services by better anticipating demand and reducing waste and pollution. All of these aim to make smart cities sustainable while improving the functions of cities through digitalization [33]. It is crucial to look at critical factors such as sustainability, ecosystems and digital citizens to achieve the main goals of improving the quality of life of smart cities, providing efficient and optimum services, and thus making the operation of the city smart through digitalization [34]. Technological interventions in daily processes have led to the rise of manageable and accessible smart ecosystems. These ecosystems; governance, transport, agriculture, logistics, maintenance, training and all aspects of everyday life such as health services and automated ways with the help of smart devices to ensure that they can be controlled remotely. Sensors and trainers embedded in smart appliances that sense the environment to facilitate proper decision making are located at the basis of the smart cities [12]. Minimal energy-consuming sensors, wifi networks, digital supervision, automatic data stream processing and utility management systems are just a few examples of digitization and opportunities for smart cities [22]. The smart city is mainly focused on applying next-generation information technologies, sensors and equipment to all walks of life, such as power grids, bridges, buildings, tunnels, hospitals, railways, roads, water systems, oil, dams and gas pipelines and other objects around the world [17]. The smart city includes several electronic objects that interact and communicate through wired and wireless networks, as well as deploying smart platforms and running related services efficiently [35]. A wide variety of electronic sensors are used to efficiently manage assets and resources and collect data. Smart cities have different approaches for analyzing, making decisions, collecting data from devices, citizens and entities used to control transportation systems, power plants, traffic, water supply networks, law enforcement, information systems and others [36, 37]. Subjects such as augmented and virtual reality, big data analysis and discovery, broadband, cognitive/artificial intelligence, internet of things (IoT), real-time, cloud, mobile are topics adopted by cities in the journey of creating smart digital reality [38].

A smart city is a smart and interconnected city that aims to improve the quality of life of its people using information and communication technology (ICT). However, internal linkages make it highly vulnerable to security attacks [39]. Cybersecurity threats are a major obstacle to the realization of the benefits of smart city applications. Because many smart city applications are networked implementations, they can be attacked to potential cyberattacks same as other network applications [26]. Effective analysis is required to identify these attacks and prevent them all together quickly, or at least reduce the associated risks and impacts. Therefore, it is essential to build a solid architecture that not only provides smart city services but also addresses security issues [39].

Another point of view for smart cities is the concept of slow and smart cities called 'Cittaslow' (slow city). Cittaslow is a non-profit association founded in Orvieto (Italy) on 15 October 1999 bringing the mayors of small and medium-sized towns together. Since then, it has become a worldwide city network. The idea of Cittaslow first arose in the late nineties by adopting the original idea of Paolo Saturnini, then mayor of Greve in Chianti in Italy, focusing on the positive side of slowness, sustainability and social justice. Inputting this idea forward, Paolo Saturnini was inspired by Carlo Petrini, founder of the international slow food movement, and his slow food experiences. The main purpose of the Cittaslow movement is to preserve the spirit of the community and at the same time pass knowledge to new generations to make them aware of their cultural heritage. In addition to this, it is to ensure sustainable development by considering social and environmental interests. Their motto is "There's no Smart without Slow", so if there is no slowness, there is no cleverness. To become a Cittaslow settlement or city, that location must go through a specific certification process. Certification of the settlement is associated with 72 quality requirements divided into 7 macro areas. These 7 macro areas are:

- Energy and environmental policies

- Infrastructure policies

- Quality of urban life policies

- Agriculture, tourism and tradesman policies

- Policies for hospitality, awareness and education

- Social solidarity

- Partnerships

Some of these requirements are mandatory and some are optional criteria. The 10th sub-heading of energy and environmental policies is the "reduction of public light pollution" criterion and is one of the mandatory criteria [40].

Bosch P. et al. prepared a report called 'CITYkeys' within the scope of the EU project to evaluate smart city projects in 2017. This report describes the choice of indicators for evaluating smart city projects and the matching indicators at the city level. Thanks to the report, the non-project situation can be compared with the situation after the application of the project, and the difference created by the project can be identified, thus enabling the comparison of projects with each other. Starting with the definition of smart city and smart city projects, indicators that can function as Key Performance Indicators to monitor the progress towards city and project goals have been selected. The indicators are focused on tracking a city's evolution towards a smarter city. Indicators, taking into account the wishes of the cities and citizens; It is organized within an extended sustainability framework that includes the themes of people, planet, favour, governance and diffusion. The ultimate goal of CITYkeys is to support the acceleration of large-scale deployment of smart city solutions and services to impact the major societal challenges 
surrounding the continuous growth and concentration of cities. At the same time, it contributes to the realization of the 20/20/20 energy and climate targets of the European Union. (20/20/20: Energy-related targets determined by the European Union for the years 2020, 2030 and 2050). For this reason, CITYkeys aims to facilitate the exchange of information between stakeholders in projects or cities through a common integrated performance measurement framework, to build trust in solutions, and to accelerate the transition to low-carbon and sustainable smart cities by making it easier to track progress. Table 1 shows the frame and subtitles of CITY keys indicators $[10,41]$.

TABLE I

\begin{tabular}{|c|c|c|c|c|}
\hline \multicolumn{5}{|c|}{ CITYkeys INDICATORS FRAMEWORK [41]. } \\
\hline People & Planet & Prosperity & Governance & Propagation \\
\hline Health & $\begin{array}{l}\text { Energy and } \\
\text { mitigation }\end{array}$ & Employment & $\begin{array}{l}\text { Multi-level } \\
\text { governance }\end{array}$ & Scalability \\
\hline Safety & $\begin{array}{l}\text { Materials, water and } \\
\text { land }\end{array}$ & Equity & Organization & Replicability \\
\hline Access to (other) services & Climate resilience & Green economy & $\begin{array}{l}\text { Community } \\
\text { involvement }\end{array}$ & \\
\hline Education & Pollution and waste & Economic performance & & \\
\hline $\begin{array}{l}\text { Diversity and social } \\
\text { cohesion }\end{array}$ & Ecosystem & $\begin{array}{l}\text { Attractiveness and } \\
\text { competitiveness }\end{array}$ & & \\
\hline $\begin{array}{l}\text { Quality of housing and the } \\
\text { built environment }\end{array}$ & & Innovation & & \\
\hline
\end{tabular}

\section{B. Light Pollution}

We illuminate our surroundings at night to see better, to be in a better environment, to work more easily, to feel safer, to improve visibility on roads and intersections, to make historical buildings or places that are desired to attract attention. In the trade or tourism sector, we also make lighting to make more attractive advertising and gain customers by increasing visibility. [42]. Lighting has become a necessity for meeting aesthetic needs and physiological comfort in human life [43]. Lighting is the process of providing visibility by sending light from a specific light source to an object or environment. The basis of the lighting concept is considered to be light; however, the aim of lighting is to visualize the illuminated environment with a light source [44]. Urban lighting affects both the comfort of lighting and the health of living creatures (human, animal and plants) in many dimensions [3]. The wrong selection and misdirection of the fixtures and lamps used to cause light trespass, glare, vertical light and excessive light in outdoor lighting [42].

Today, both very poor lighting applications in Turkey as well as all over the world are available and these wrong practices are becoming more common. As a result, a new type of pollution called "Light Pollution" occurs [45, 46, 47, 48]. Light pollution is the use of light in the wrong place, wrong amount, wrong direction and at the wrong time. Although it is not toxic like air pollution and water pollution, using excessive and in the wrong places means ineffective lighting; As a result, a significant portion of the energy spent to produce light is wasted [42]. Light pollution; is also expressed as the misuse of light in a way that causes energy waste, prevents astronomical observations and creates effects that spoil natural life [49]. The relationship between spatial light intensity and vision quality can be controlled with luminaires for lighting situations that are made in the wrong place, wrong amount, wrong direction and wrong time. The design of the luminaires can be intervened. Artificial lighting used outdoors is the primary source of light pollution. Lighting should be done in the right place, in the right direction, at the right amount and at the right time. The problem is not in the lighting, but in the incorrect lighting [46]. The right lighting is the most crucial factor that will prevent light pollution and energy consumption [49].

In cases where visual health and comfort are ignored, illumination may cause discomfort, contrary to facilitation. The problem of light pollution may occur in cases such as the application of incorrect lighting fixtures in outdoor areas, incorrect adjustment of the intensity, direction and colour of the light. Systems like unnecessary store lighting, inefficient or low-intensity street lighting fixtures, illuminated billboards that abruptly change intensity and colour to attract people, etc. that do not allow homogeneous light distribution are a part of light pollution and create visual pollution both in terms of visual health and comfort and aesthetics [3, 50]. In general, sources of light pollution can be listed as follows:

- Street lighting such as roads, streets, highways, intersections, toll stations,

- Park, square and garden lightings,

- The lighting of parking lots and sports areas,

- Illumination of touristic facilities,

- Airports, ports and train stations lightings,

- Exterior lighting of buildings,

- Advertising boards,

- Lights overflowing from houses and buildings,

- Security lighting etc.

An important part of the studies on light pollution is to measure how heterogeneous spatial light distribution is related to the lighting system. Light pollution is mainly studied for the characterization of sky glow and the identification of street lamps. This process is done in fields such as astronomy using digital cameras, solar cells, Sky Quality Measurement (SQM) sensors or other remote sensing sensors. Satellite images, the visual equivalent of information perceived by a sensor, can be 
used to provide information about artificial nighttime radiation. Due to artificial night radiation, the impact area of atmospheric pollution increases [51, 52, 6]. Urban studies should include a strong foundation of analysis that allows for an interdisciplinary diagnosis to describe the various conditions of urban settlements [53].

One of the fastest-growing types of environmental degradation is light pollution. Pollution levels above natural nighttime lighting levels provided by moonlight and starlight are increasing exponentially. Several effective practices have been identified to limit this pollution: The use of shields on the luminaire to prevent direct upward light, especially at low angles above the horizon; avoiding excessive lighting, that is, excessive lighting; limiting the lighting to the required space and time, etc. However, even if it provides optimal control of light distribution and the appropriate amount of light is used, some light emission remains upward due to reflections and atmospheric scattering from luminous surfaces. At this point, the effect of "residual light pollution" on the environment is undeniable and must be limited [7]. The degree and type of light pollution can be understood depending on the actions of active individuals in society and the characteristics that transform the society into an urban system. The emission function of the pollutant source is determined by the change of these factors [51]. Dust, water vapour, and other particles scatter and reflect light emitted into the atmosphere. This results in the glow over urban areas in the sky sometimes referred to as atmospheric or astronomical light pollution [49]. Understanding night sky brightness is an important and challenging problem to solve. Light transforms atmospheric optics in a blurry environment and converts emissions. Light pollution is directly linked to optical processes in a constantly changing atmospheric environment. The emission function is qualified by the characteristics of public lighting systems that change irregularly [1].

There should be a benchmark and a standard in lighting [3]. Today, many countries are making legal regulations to limit light pollution. For this purpose, the Canary Islands, where large observatories are located, and the states of Arizona, Maine and Texas in the USA are protected by special laws. Related laws and regulations are prepared in more than sixty local governments in the USA and countries such as Canada, Belgium, Germany, France, England, New Zealand and Japan [54]. The United Nations Space Convention has defined space as "the common space of all humanity". A decision was taken at the Conference on the Use of Space for Peaceful Purposes held in Vienna in July 1999. With this decision, the member states of the United Nations are required to control the pollution of the sky by light and other reasons, both for the benefit of science, energy-saving, natural environment, night safety and comfort, and for the benefit of the national economy. In the General Assembly of the International Astronomical Union (IAU) held in Brazil in August 2009, the importance of protecting access to the uncontaminated sky for all humanity was emphasized in terms of education and culture. Also, each country was asked to preserve the astronomical quality of the areas suitable for scientific observation of the universe [55].
The photos in Figure 1 were taken by Jeff Dai in a settlement in Kaihua, China, in 2019. The change in the sky is visible when the public turns off most of the lights. While only Sirius and Betelgeuse stars are visible when the lights are on (before photo), when most of the lights are turned off (after photo) thousands of stars with the curved belt of our Milky Way galaxy are visible [56].

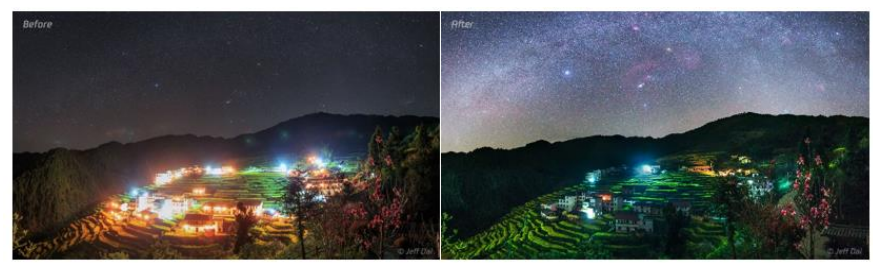

Fig. 1 The difference seen in the sky when the lights are on and off in the city of Kaihua [56].

In Figure 2, 6 different sky views taken from various locations throughout Slovakia are combined. The photographs were taken with the same equipment, at the same time of the night, and were subjected to the same digital post-processing. The sky is entirely dark in the dark sky (far right, in the countryside), while the stars are not visible in the city sky (far left) [57].

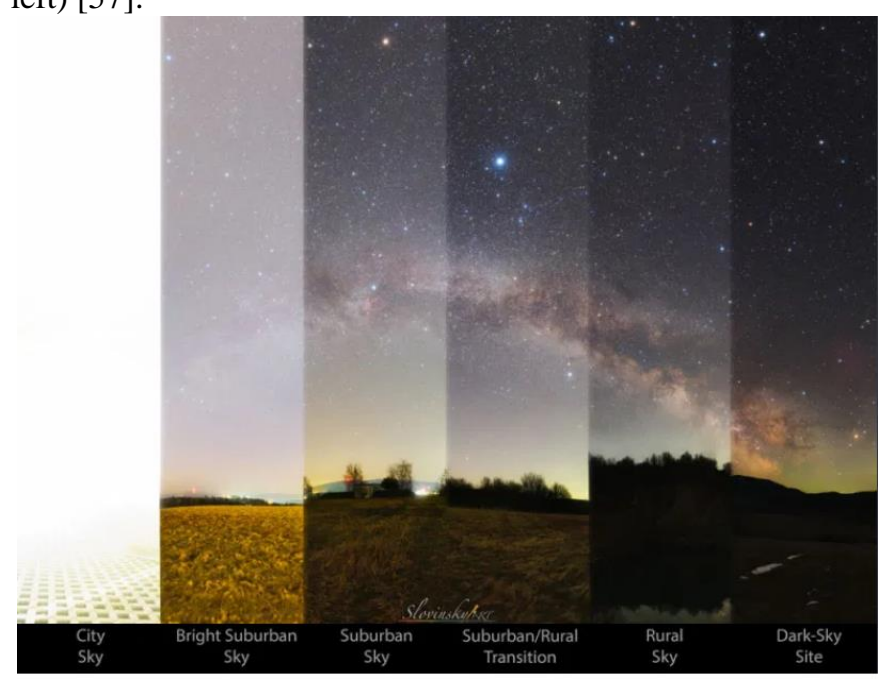

Fig. 2 Sky view in different settlements in Slovakia [57].

Figure 3 shows photographs taken in a lakeside town in the city of Monte Patria, Chile. All the lighting fixtures in the upper photo have been renewed using less few of luminaires and lower intensity. In this way, light pollution is prevented without sacrificing safety, tourism and visual comfort [58]. Few examples of light pollution are seen here, with a significant difference observed in just a small settlement. Based on this, the extent of pollution is better understood globally. As a result, what should be done to prevent light pollution?

- Informing society about light pollution,

- Developing standards for outdoor lighting and fixtures by examining the recommendations of the International DarkSky Association (IDA) and the International Lighting Commission (CIE) in other countries, 
- Ensuring that technical specifications and regulations are adapted to developing technology [11],

- Preferring dark sky-friendly lighting,

- Building smart cities.

In this way, energy and natural resources will be saved, lighting costs will be reduced, night security will be improved, living life and nature will be protected from a negative light, and the beauty of the sky will be preserved for the next generations [11].

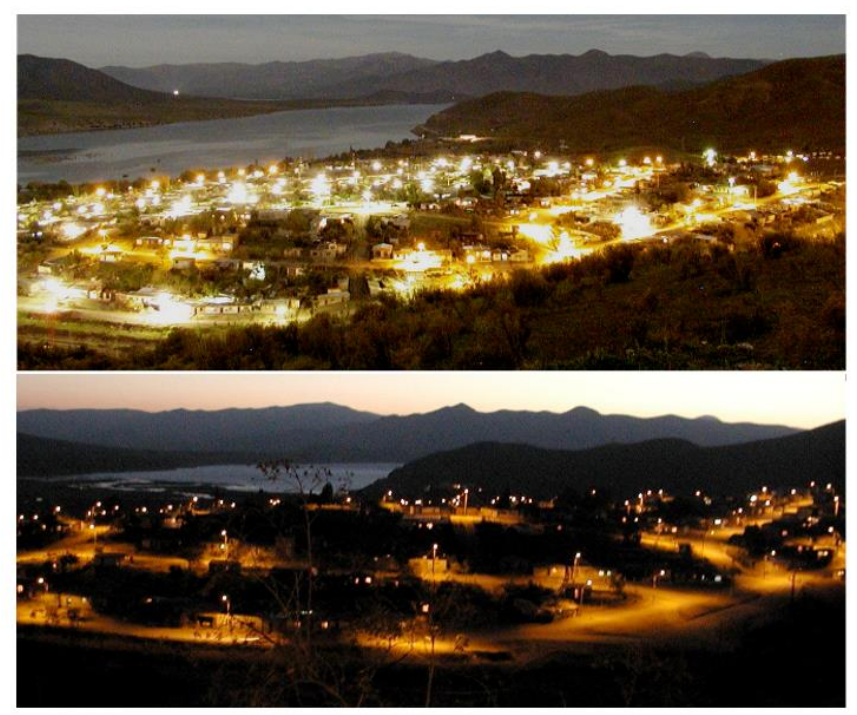

Fig. 3 Dark sky created by changing fixtures in Monte Patria, Chile [58].

\section{Outdoor Lighting}

Outdoor lighting is done at night to meet various human needs and perform many functions. The primary classification of outdoor lighting depends on the task required, the type of outdoor area and the activities performed. In European Union countries, lighting requirements for frequently used outdoor work areas are regulated according to the standards. However, since the lighting of natural and architectural objects is not standardized, recommendations have been made in technical reports such as the International Commission on Lighting (Commission Internationale de l'Eclairage: CIE) report [4]. The primary purpose of an outdoor lighting application at night is the need for security. Lighting realization means fulfilling the lighting conditions in which visual functions can be carried out comfortably and effectively. Generally, outdoor lighting: Business and general activities; drivers and pedestrians; decoration and colouring; provided for sports activities. Requirements other than these four basic requirements are: Lighting criteria and parameters; Electrical installation requirements and their energy consumptions, control systems and safety; Simulation and verification methods; It is connected with lighting equipment and maintenance systems [59].

Outdoor lighting applications have changed significantly in recent years as functional lighting increasingly leads to a better quality of light vision. The traditional role of security lighting has evolved towards the use of lighting for urban refinement. This is now an important issue for new lighting strategies. In this context, other development paths have been followed in lighting design. With the emergence of a more theatrical diffusion of light in contemporary culture, the use of new types of lighting to enhance the urban night experience has become increasingly common. This situation has led to a severe change in the scale, scope and policies of urban lighting strategies. Thus, it has caused an increase in the field of intervention and application in urban lighting. As a result, an increasing number of local governments have begun to see urban lighting as a potential urban development tool. Local governments are under the pressure of several different factors, such as budget cuts, technological advances and demands to mitigate climate change. Accordingly, they turn towards changes in lighting strategies to reduce their energy consumption and financial burden [60].

Today, energy efficiency plays a vital role in the design of indoor and outdoor lighting systems [61]. Nowadays, where the importance of sustainable development is progressively understood, the importance of energy efficiency studies is increasing. Worldwide, grid-based electrical lighting consumes $19 \%$ of total global electricity generation, with slightly more than is used by the Organization for European Economic Cooperation and Development (OECD) countries for all purposes [62]. The lighting of streets and buildings, on the other hand, accounts for $75 \%$ of the lighting demand for electricity. Intelligence and efficiency play an important role in making a big difference in power consumption, especially in outdoor lighting systems where a large amount of energy is wasted using traditional light bulbs. For these reasons, energysaving is significant in street lighting systems. Now the primary trend of developing lighting products is to ensure products are energy efficient and environment friendly, and to improve the performance of manufactured products [63, 61].

One of the central focus areas for enhancing the efficiency of complicated street lighting systems is the application of automatic control systems. Everything in the world becomes smarter by being connected and can work on its own without any human interface. IoT has often been used to do this, making everything smart. Outdoor lighting systems can also save more energy than using the IoT if they are made smart enough to operate without human interaction. Modern automatic outdoor lighting systems allow the operator to manage the complete lighting system and each luminaire individually from a central console. Outdoor luminaires should be equipped with advanced electronic control equipment systems to control and handle the operation of luminaires [63, 61]. The lighting systems to be applied should be able to optimize the energy consumption of street lamps and operate the street lamps smartly and effectively to increase efficiency [61]. However, street lighting control systems do not require time-based control as with traditional feedback loops. Control algorithms in such installations are based on a schedule, taking into account information about operating parameter changes (light intensity, usage, number of working lights) provided by specific sensors [64].

Recently, there has been a growing awareness in research and policy that artificial light is not entirely harmless [60]. Accordingly, the increase in light pollution has triggered a large number of research groups to research the impact of 
artificial light and especially Light Emitting Diode (LED) and colour-rich sources on sky glare [65]. Also, the emphasis has been placed not only on the quality of illumination but also on the subjective interpretation of light impressions and the adjustment of light to the human circadian rhythm [66]. In this context, human-oriented lighting applications aiming to balance the visual, emotional and biological benefits of humans have gained importance [67]. Also; $\mathrm{CO} 2$ emissions related to global lighting (from grid-based electrical lighting, fuel-based lighting, and vehicle lighting) account for up to $70 \%$ of global emissions from passenger cars (1900Mt). Considering all these effects, it is seen once again that an intelligent outdoor lighting system is needed that is energy efficient and can minimize the disadvantages caused by available outdoor lighting control systems [62].

Limitation of light pollution and disturbing lighting can usually be evaluated at the project stage using special lighting computation software and applying varied implementation guidelines. Failure to make field measurements during the commissioning of a lighting installation or during its lifetime increases the negative effects such as excessive illumination, the possibility of light pollution and $\mathrm{CO} 2$ emission. New technology in lighting controls and smart lighting fixtures helps guide adaptive lighting. Several studies also show that outdoor adaptive systems have the potential to reduce the effects of light pollution [65]. Luminaires, which can be dimmed depending on the movement or the ambient light level, and can dim when necessary, are one of the critical parts of smart outdoor lighting.

Light pollution is directly linked to the energy waste of an outdoor lighting installation. This situation creates the need to redefine the energy efficiency problem. It also makes sense to combine outdoor lighting problems with a sustainable development approach. Looking at the analyzed problem with a conscious approach, it is possible to reduce the negative effects of light pollution significantly. This means that thanks to these solutions, it is possible to create dark sky protection areas in selected locations around the world. Thus, artificial light has many significant effects on the environment at night. An outdoor lighting installation should be analyzed in a sophisticated way, taking into account all of the crucial factors such as spectral power distribution of luminaires or light sources. Also, other factors such as safety, environmentalism, economy and aesthetics should be considered. Therefore, there seems to be a need to implement a multi-criteria procedure based on the evaluation of the luminous environment, energy efficiency and light pollution for any outdoor lighting installation [59].

The light pollution component of outdoor lighting is produced directly by the base component. That is, it is the luminous flux that radiates directly into the upper hemisphere and does not interact with any surface. Additionally, the reflected component is the sum of the reflection of the light on the illuminated surfaces and the reflection of the light from the surfaces not intended to be illustrated [65]. To reduce the effect of this situation, it is essential to choose the right luminaire and use the right lighting method. As can be understood from the definitions of light pollution, the most important of all is to make the right lighting. Outdoor lighting has two essential elements: light source and luminaire. Choosing the right lamp and luminaire has a vital place in combating the negative effects of outdoor lighting on humans and nature (light pollution, CO2 emission, energy consumption, etc.). In addition, the lighting method that is directed only to the area or object to be illuminated and does not create negative effects such as reflection or glare, regardless of the purpose of use, is of great importance. In summary, in outdoor lighting:

- Selection of suitable elements for the purpose,

- Using the right lighting method,

- Using lamps that consume less energy while serving the same purpose,

- By using smart control and monitoring systems [62],

a useful illumination will be provided in every respect, that is, the main goal will be achieved.

\section{Prevention of Light Pollution in SMARt Cities}

Street lights used today are automatically switched on and off according to the day/night sensor or the timer. Recently, LED lamps with a variety of advantages have begun to be replaced by conventional light sources. In addition to this solution that comes to mind first, using a smart outdoor lighting system provides benefits such as reducing energy consumption due to better control of light usage, providing contextual lighting to improve public safety in critical situations or areas of interest, reducing maintenance and asset management costs thanks to data from street light sensors etc. [68].

The benefits of the smart lighting system can be listed as follows:

- To reduce energy costs,

- Save time and energy (helping the maintenance team in the field solve problems quickly),

- To reduce maintenance costs,

- To provide efficient business,

- Remote monitoring of electrical parameters,

- To eliminate the negative psychological effect of incorrect lighting,

- To reduce light pollution caused by incorrect lighting,

- Providing safe lighting,

- Lamp on-off, dimming etc. remote control of operations, remote management of fixtures,

- Fault detection can be made remotely and the fault location can be determined instantly and intervened immediately,

- To be able to monitor the lighting load on the network etc. [68, 69].

Smart outdoor lighting systems considered within the scope of smart cities in the literature generally draw attention to energy saving. However, the issue of light pollution, which is getting more serious day by day, is an issue that should be taken into consideration. One of the most important advantages of smart cities in terms of environment and ecology is to reduce light pollution and thus prevent the negative consequences of light pollution. 


\section{CONCLUSION}

In today's world, energy consumption is gradually increasing due to urbanization in developed and developing cities. The increasing demand has to be met, and this may cause problems in existing infrastructures and systems. Besides, some negative impacts arising from human activities cause serious damages to the environment (hence energy resources), human beings, nature and disrupt economic, social and environmental balances. Outdoor lighting, which is one of the requirements of cities, has a significant share in energy consumption. If outdoor lighting is not made correctly, energy consumption increases and the environment is harmed by causing light pollution. Besides, incorrect outdoor lighting affects the health and quality of life of humans and other living creatures.

In changing conditions, it is crucial to use available resources economically and to prevent negative consequences in order not to compromise human comfort and not to affect the environment negatively. When designing a system, it is not right to only consider needs. The needs should be met with the lowest cost and least negative impact, with the highest benefit. Therefore, after considering all the conditions of the system to be designed, it should be designed following the purpose. At this point, smart systems come to mind. Outdoor lighting is one of the basic needs of people in particular and cities in general. Therefore, all conditions should be taken into consideration while meeting this need. In this direction, to prevent negative consequences while making outdoor lighting, there is a need for smart systems that will reduce energy consumption and avoid light pollution by ensuring the correct outdoor lighting. A smart outdoor lighting system includes a luminaire and network system with very low energy consumption and uses correct ways that do not cause light pollution. Considering that the share of outdoor lighting in the grid is approximately $14.75 \%$, the savings to be made in this area have a significant contribution to energy production. Besides, when the dark sky deprivation caused by light pollution is eliminated with correct and smart outdoor lighting, people, the environment and scientific studies will be contributed.

In this study, the demands arising from urbanization, outdoor lighting requirements, and light pollution are mentioned and transforming into smart cities is proposed as a solution. Various studies, reports and projects in the literature have shown that smart cities have become a necessity in our age. In fact, smart cities mean that everything necessary to meet human needs is done correctly. Smart cities mean that doing everything right to meet human needs. Developing technology has made smart systems very useful, accessible and sustainable. Therefore, smart cities have the potential to offer a more livable and sustainable world to people and other living creatures by taking advantage of technological opportunities. Thanks to these possibilities, it has become easier to build smart outdoor lighting systems within the scope of smart cities in residential areas (especially in places where urbanization is high). Considering the long-term benefits of smart outdoor lighting, the necessity of these systems is an undeniable fact. Smart outdoor lighting ensures that the necessary things to meet the requirements are done correctly and negative effects (unnecessary energy consumption, light pollution, security negligence, etc.) are eliminated. As a result; in a world where energy resources are diminishing, the sky is losing its brightness and the balance of living life is gradually deteriorating, something needs to be done to prevent negative conditions. It is a fact that human makes his living conditions difficult with his hand, but also harms nature seriously. While taking the advantage of the natural and artificial possibilities in the world, humans have to look out for the lowest damage with the highest benefit. In this context, we can say that it is both logical and very necessary to design a smart outdoor lighting system for outdoor lighting requirements.

\section{REFERENCES}

[1] Y. Lu and N. C. Coops, "Bright lights, big city: Causal effects of population and GDP on urban brightness.", PLoS ONE, 13(7). https://doi.org/10.1371/journal.pone.0199545, 2018.

[2] A. Schneider, M. A. Friedl and D. Potere, "A new map of global urban extent from MODIS satellite data.", Environmental Research Letters, 4(4). https://doi.org/10.1088/1748-9326/4/4/044003, 2009.

[3] E. Korkmazer, Y. Bektas, M. Aykanat, S. Jevedzade, and Y. Caymaz, G. F., "Study of Light Pollution in Urban Lighting in Nisantasi Example.", Journal of Contemporary Urban Affairs, 3(2), 8-15. https://doi.org/10.25034/ijcua.2018.4696, 2019.

[4] Technical Report of Commission Internationale de l'Eclairage CIE 094 Guide for Floodlighting; CIE: Vienna, Austria, 1993.

[5] K. W. Riegel, "Light Pollution: Outdoor lighting is a growing threat to astronomy.", Science (New York, N.Y.), 179(4080), 1285-1291. https://doi.org/10.1126/science.179.4080.1285, 1973.

[6] D. Ziou and F. Kerouh, "Estimation of light source colours for light pollution assessment.", Environmental Pollution, 236, 844-849. doi:10.1016/j.envpol.2018.02.022, 2018.

[7] F. Falchi, P. Cinzano, C.D. Elvidge, D.M. Keith, A. Haim, "Limiting the impact of light pollution on human health, environment and stellar visibility.", Journal of Environmental Management. 2011;92(10):27142722. doi:10.1016/j.jenvman.2011.06.029, 2011.

[8] E. Uygun and S. Görgülü. "Investigation of Home Type Heliostat Systems Daylighting Performance With Lighting Simulation Method." European Journal of Technique (EJT) 11.1: 7-12.

[9] International Dark Sky Association, 2010. Visibility, Environmental, and Astronomical Issues Associated with Blue Rich White Outdoor Lighting. Technical Report.

[10] P. Bosch, S. Jongeneel, V. Rovers, H. M. Neumann, M. Airaksinen and A. Huovila, "CITYkeys indicators for smart city projects and smart cities." Technical Report, DOI: 10.13140/RG.2.2.17148.23686, 2017.

[11] M. S. Taner, "Işık kirliliği ölçümü için okullarda yapılabilecek deneysel bir etkinlik önerisi”, Anadolu Öğretmen Dergisi, 3(1), 74-84. DOI: 10.35346/aod.566401, 2019.

[12] M. A. Ahad, S. Paiva, G. Tripathi and N. Feroz, "Enabling Technologies and Sustainable Smart Cities", Sustainable Cities and Society, 61. https://doi.org/10.1016/j.scs.2020.102301, 2020

[13] Z. Karagöz Küçük and N. Ekren, "Akıllı Mutfak İçin Tasarlanmış Sistemler Üzerine Bir Derleme", International Periodical of Recent Technologies in Applied Engineering, 2 (1), 25-34. Retrieved from https://dergipark.org.tr/en/pub/porta/issue/56304/721927, 2020.

[14] V. Albino, U. Berardi and R. M. Dangelico, "Smart Cities: Definitions, Dimensions, Performance, and Initiatives", Journal of Urban Technology, 22:1, 3-21, DOI: 10.1080/10630732.2014.942092, 2015.

[15] D. S. Chirov and Y. A. Kochetkov, "Optimization of the Placement Topology of Spatially Distributed Receiving and Transmitting Posts for the Detection of Small UAVs in the Conditions of a "Smart City."' 2020 Systems of Signal Synchronization, Generating and Processing in Telecommunications doi:10.1109/synchroinfo49631.2020.9166037, 2020.

[16] M. A. Özçelik and M. Yilmaz. "Gün Ișı̆ı̆ Alan Mekanda Önerilen Bölgesel Kontrollü Akıllı LED Sistem ile Flüoresan ve Normal LED Aydınlatmanın Karşılaştırılması." El-Cezeri Journal of Science and Engineering 6.2: 270-281 
[17] K. Su, J. Li, and H. Fu, "Smart city and the applications", 2011 International Conference on Electronics, Communications and Control (ICECC), 2011.

[18] South African Local Government Association (SALGA), "SMART CITIES" in.KNOW .vation, Produced by Corporate Strategy \& Research office of the CEO, http://www.cpsLco.zalwpcontentluploads/20 15/05IFINALSALGAPUBLICATIONLOWRES.pdf, 2015.

[19] N. Villanueva-Rosales, R. L. Cheu, A. Gates, N. Rivera, O. Mondragon, S. C. C. Ferregut, C. Carrasco, S. Nazarian, H. Taboada, V. M. Larios, L. Barbosa-Santillan, D. Prochazkova, M. Svitek, O. Pribyl and T. Horak, "A collaborative, interdisciplinary initiative for a smart cities innovation network." 2015 IEEE 1st International Smart Cities Conference, 2015. https://doi.org/10.1109/ISC2.2015.7366179, 2015.

[20] B. Veselinović Savković, A. Schweigkofler, O. Savković, M. Riedl and D. T. Matt, "Validation Methodology for a Citizen-centric Smart-City Platform." Proceedings of ISPIM Conferences, 1-12., 2020.

[21] K. K. Nair, M. M. Pillai, S. Lefophane and H. D. Nair, "Adaptation of Smart Cities in the South African Internet of Things Context", 2020 International Conference on Artificial Intelligence, Big Data, Computing and Data Communication Systems (IcABCD), 2020 International Conference On, 1-6. https://doi.org/10.1109/icABCD49160.2020.9183832, 2020.

[22] G. Suciu and A.-M. Tudor, "Promoting a Business through Events in a Smart City. " ELearning \& Software for Education, 3, 150-155. https://doi.org/10.12753/2066-026X-20-189, 2020.

[23] L. Zlámal, "Smart City and Smart Region Concept in Zlín and Trenčín Regions." Social \& Economic Revue, 17(4), 61-70., 2019.

[24] M. Yilmaz "Real measure of a transmission line data with load fore-cast model for the future." Balkan Journal of Electrical and Computer Engineering 6.2 (2018): 141-145.

[25] H. Chourabi, T. Nam, S. Walker, J. R. Gil-Garcia, S. Mellouli, K. Nahon, H. J. Scholl, "Understanding Smart Cities: An Integrative Framework." 2012 45th Hawaii International Conference on System Sciences. doi:10.1109/hicss.2012.615, 2012.

[26] N. Mohamed, J. Al-Jaroodi and I. Jawhar, "Opportunities and Challenges of Data-Driven Cybersecurity for Smart Cities." 2020 IEEE Systems Security Symposium (SSS). doi:10.1109/sss47320.2020.9174388, 2020

[27] [Online]

Available: https://www.idc.com/getdoc.jsp?containerId=prUS44159418, Accessed on 31 January 2020

[28] J. McClellan, Jimenez, and G. Koutitas (Eds.), "Smart Cities: Applications", Technologies, Standards, and Driving Factors (pp. 209 233). Springer International Publishing. https://doi.org/10.1007/978-3319-59381-4-13, 2018

[29] C. Rotuna, A. Gheorghiță, A. Zamfiroiu, D. Smada Anagrama, "Smart city ecosystem using blockchain technology", Inform. Econ, 23, 41-50, 2019.

[30] K. Baculáková "Selected Aspects of Smart City Concepts: Position of Bratislava." Theoretical and Empirical Researches in Urban Management, 15(3), 68., 2020.

[31] J. B. Porto and M. Oliveira, "The smart cities methodology based on public value: The first evaluation cycle.", BAR - Brazilian Administration Review, 17(1). https://doi.org/10.1590/18077692bar2020190048, 2020.

[32] R. Giffinger, C. Fertner, H. Kramar, R. Kalasek, N. Pichler-Milanović, E. Meijers, "Smart cities" Ranking of European medium-sized cities, http://www.smartcities.eu/download/smart_cities_final_report.pdf, 2007.

[33] K. Hernandez, "Achieving Complex Development Goals along China's Digital Silk Road", K4D Emerging Issues Report, Brighton: Institute of Development Studies, 2019.

[34] B. Krishnan, S. Arumugam and K. Maddulety, "Critical success factors for the digitalization of smart cities.", International Journal of Technology Management \& Sustainable Development, 19(1), 69-86. https://doi.org/10.1386/tmsd_00016_1, 2020.

[35] A. AlDairi and L. Tawalbeh, "Cyber Security Attacks on Smart Cities and Associated Mobile Technologies.", Procedia Computer Science, 109, 1086-1091. https://doi.org/10.1016/j.procs.2017.05.391, 2017.

[36] T.J.H. Gracia and A. C. García, "Sustainable Smart Cities. Creating Spaces for Technological", Social and Business Development. Boletín
Científico de Las Ciencias Económico Administrativas Del ICEA, 6(12), 2018.

[37] A. M. Rashid, A.A. Yassin, A.A. Alkadhmawee and A.J. Yassin, "Smart

security: Face-based image retrieval model using gray level cooccurance matrix.", Journal of Information and Communication Technology, 19(3), 437-458., 2020.

[38] M. Visan and C. Ciurea, "Smart City: Concepts and two Relevant Components.", International Journal Of Computers Communications \& Control, 15(2). doi:10.15837/ijccc.2020.2.3867, 2020.

[39] T. Qamar and N. Z. Bawany, "A Cyber Security Ontology for Smart City.", International Journal on Information Technologies \& Security, 12(3), 63-74., 2020.

[40] [Online] https://www.cittaslow.org

[41] [online] http://www.citykeys-project.eu

[42] [Online] https://tug.tubitak.gov.tr/sites/images/tug/isik_kirliligi.html

[43] P. Boyce, "Human factors in lighting.", Lighting Research Center (2nd ed.). London: Taylor \& Francis. https://www.crcpress.com/HumanFactorsin-Lighting/Boyce/p/book/9781439874882, 2013.

[44] Ş. Sirel, "Aydınlatma ve Mimarlık [Lighting and Architecture]", $\begin{array}{llll}\text { Tasarım } \quad \text { [Design], 110: } & \text { 98- }\end{array}$ http://www.yfu.com/yazilar/TasDer110- AydveMim.pdf, 2001.

[45] Z. Aslan, "Işık kirliliğ̌i”, TÜBİTAK Bilim ve Teknik Dergisi, Vol.362 pp.66-69, 1998.

[46] Z. Aslan, "Işık Kirliliği”" konferanslar: Öğretmenlere yönelik sunumlar, Astronomi Öğretmen Seminerleri Serisi (AÖS-3(Antalya), AÖS5(ODTÜ-Ankara) ve AÖS-13 (ODTÜ-Ankara) http://www.astrobilgi.org/category/etkinlik/, 2015.

[47] Z. Aslan and Z. Tunca, "Işık Kirliliği”", Sunum.,17. Ulusal Gökyüzü Gözlem Şenliği 31 Temmuz-3 Ağustos, Saklıkent Antalya, 2014

[48] D. Çetegen and A. Batman, "Işık kirliliği.", İstanbul Teknik Üniversitesi Elektrik Elektronik Fakültesi Yayınları. Yayın No:9, 2005.

[49] H. Dokuzcan, "Işık Kirliliği Açısından Kent Aydınlatması ve Taksim Meydanı Örneği", Yüksek Lisans Tezi, Bahçeșehir Üniversitesi, Fen Bilimleri Enstitüsü, Mimarlık Anabilim Dalı, İstanbul, 2006.

[50] J. Meier, U.Hasenöhrl, K. Krause and M. Pottharst, "Urban lighting, lightpollution, and society", New York : Routledge, Taylor \& Francis Group, 2015.

[51] J.A. Pichardo-Corpus, H. A. Solano Lamphar, R. Lopez-Farias and O. Delgadillo Ruiz, "Spatio-temporal networks of light pollution.”, Journal of Quantitative Spectroscopy and Radiative Transfer, 253. https://doi.org/10.1016/j.jqsrt.2020.107068, 2020.

[52] Héctor Antonio Solano Lamphar, and Miroslav Kocifaj, "Light pollution in ultraviolet and visible spectrum: effect on different visual perceptions.", PLoS ONE, 8(2), e56563. https://doi.org/10.1371/journal.pone.0056563, 2013.

[53] J. Marull, J. Pino, J. M. Mallarach and M. J. Cordobilla, "A Land Suitability Index for Strategic Environmental Assessment in metropolitan areas.", Landscape and Urban Planning, 81(3), 200-212. https://doi.org/10.1016/j.landurbplan.2006.11.005, 2007

[54] C.S. Aksay, O. Ketenoglu and L. Kurt, "Light Pollusion.", Afyon Kocatepe Üniversitesi Fen ve Mühendislik Bilimleri Dergisi Volume: 7, Issue: 2 231-236, 2007.

[55] Z. Aslan, O. Gölbaşı, D. Koçer, Z. Tunca, E. Işık, A. Yelkenci, D Bağdaş, A. Devlen, T. Özdemir, K. Yelkenci, T. Demirciler, U. İkizler, A. Karamahmutoğlu, M. Koçer, M. Mutlu, Ü. Özyar and H. İpek, "Türkiye'de gece gökyüzü parlaklığının ölçülmesi”, 8. Ulusal Aydınlatma Kongresi, 14-15 Nisan Bildiri Kitabı s:69.4, 2011.

[56] [Online] https://astro.org.sv/imagendeldia/mayo-16-2019-cielososcuros-enciendan-la-noche-mayo-16-2019-cielos-oscuros-enciendanla-noche/

[57] [online] https://astro.org.sv/imagendeldia/abril-8-2020-cielo-ruralversus-cielo-citadino/

[58] [online] https://www.darksky.org

[59] P. Pracki and K. Skarzyński, "A multi-criteria assessment procedure for outdoor lighting at the design stage.", Sustainability (Switzerland), 12(4). https://doi.org/10.3390/su12041330, 2020.

[60] E. Giordano, "Outdoor lighting design as a tool for tourist development: the case of Valladolid.", European Planning Studies, 26(1), 55-74. https://doi.org/10.1080/09654313.2017.1368457, 2018.

[61] G.T. Aditya and N. K. Prakash, "Smart and Efficient Outdoor Lighting System.", 2018 Second International Conference on Intelligent Computing and Control Systems (ICICCS), Intelligent Computing and 
Control Systems (ICICCS), 2018 Second International Conference On, 1598-1602. https://doi.org/10.1109/ICCONS.2018.8663140, 2018.

[62] S. Atis and N. Ekren, "Development of an outdoor lighting control system using expert system.", Energy \& Buildings, 130, 773-786. https://doi.org/10.1016/j.enbuild.2016.08.066, 2016.

[63] A.A. Filimonova, T. A. Barbasova and D. A. Shnayder, "Outdoor Lighting System Upgrading Based on Smart Grid Concept.”, Energy Procedia, 111, https://doi.org/10.1016/j.egypro.2017.03.230, 2017.

pp.678-688.

[64] A. Ozadowicz and J. Grela, "The street lighting control system application and case study.", Proceedings of 1st International Conference on Event-Based Control, Communication and Signal Processing, $\quad$ EBCCSP 2015. https://doi.org/10.1109/EBCCSP.2015.7300701, 2015.

[65] C. A. Bouroussis and F. V. Topalis, "Assessment of outdoor lighting installations and their impact on light pollution using unmanned aircraft systems - The concept of the drone-gonio-photometer.", Journal of Quantitative Spectroscopy and Radiative Transfer, 253. https://doi.org/10.1016/j.jqsrt.2020.107155, 2020.

[66] J. Maziarka, L. Bena and H. Wachta, "Meaning of Scotopic/Photopic Ratio of Light Sources in Lighting of Outdoor Spaces.", 2018 VII. Lighting Conference of the Visegrad Countries (Lumen V4), Lighting Conference of the Visegrad Countries (Lumen V4), 2018 VII, 1-4. https://doi.org/10.1109/LUMENV.2018.8521093, 2018

[67] Ö. Memiş, "İnsan Odaklı Aydınlatma." International Periodical of Recent Technologies in Applied Engineering, 1 (1), 30-35. Retrieved from https://dergipark.org.tr/tr/pub/porta/issue/44896/542862, 2019.

[68] N. T. Tung, L. M. Phuong, N. M. Huy, N. Hoai Phong, T. L. Dinh Huy and N. Dinh Tuyen, "Development and Implementation of Smart Street Lighting System based on Lora Technology." 2019 International Symposium on Electrical and Electronics Engineering (ISEE), Electrical and Electronics Engineering (ISEE), 2019 International Symposium On, 328-333. https://doi.org/10.1109/ISEE2.2019.8921028, 2019.

[69] F.G. Carloto, M. A. D. Costa, C. H. Barriquello, D. P. Bernardon, N. Silva Spode, L. da, Maziero, W. D. Vizzotto and F. G. Reck, "The Role of a Smart Street Lighting into a Smart Grid Environment.", 2019 IEEE PES Innovative Smart Grid Technologies Conference - Latin America (ISGT Latin America), 2019 IEEE PES, 1-6. https://doi.org/10.1109/ISGT-LA.2019.8895267, 2019.

\section{BIOGRAPHIES}

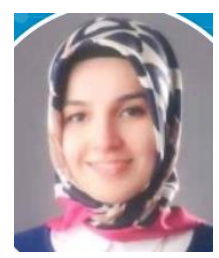

ZEHRA KARAGÖZ KÜÇÜK, she received the B.S. degree from the Electrical Engineering Department, Istanbul University, Istanbul, Turkey, in 2015, and the M.S. degrees from the Erzincan University, Erzincan, Turkey, in 2018. She is continuing $\mathrm{PhD}$ education in Marmara University Electrical and Electronics Engineering Department, Istanbul, Turkey. She is currently a lecturer at Dogus University, Vocational School Electrical Department. Her research interests include electric, lighting.

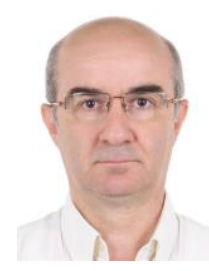

NAZMI EKREN, received the B.S. degree from the Electrical Engineering Department, Yildiz Technical University (YTU), Istanbul, Turkey, in 1987, and the M.S. degrees from the Marmara University in 1989 and $\mathrm{PhD}$ degrees from the Istanbul University in 1996. He is currently an associate professor at the Marmara University. His research interests PV systems, fabrication at Nano level and lighting. He works on tissue engineering applications, 3D-bioprinting, electrospinning. 